\title{
Family Structures in Pennsylvania and its Effect on Delinquent Acts: A Data Analysis
}

\author{
P.J. Verrecchia* and Robyn Arp
}

York College of Pennsylvania, USA

\begin{abstract}
This paper examines the effect of family structure on delinquent acts. Specifically, whether living arrangement (with both parents, one parent, etc...) has any impact on the type of delinquent act (person or drug) committed. Data for over 2,700 juveniles who committed a substantiated delinquent act in Pennsylvania were examined for possible effects. Two family structure variables had a significant relationship with drug offenses (one in the negative direction), and one family structure variable was associated with person offenses. Only one non-family structure predictor variable (age) was associated with both offense types.
\end{abstract}

Keywords: Juvenile delinquency, juvenile justice, family structure.

\section{INTRODUCTION}

The changing American family is a fertile area of research in juvenile justice. A number of changes in the American family during the past few decades have prompted controversy and debate over the meaning and implications of these trends, which include the increase in single parent families, and an increase in the number of children growing up in stepfamilies. This study explores differences in living arrangements in Pennsylvania and its effect on delinquent acts in 2012. The Pennsylvania Juvenile Court Judges' Commission (JCJC) annually publishes an overview of juvenile court dispositions which summarizes juvenile court statistical data provided by the 67 county juvenile probation departments. This includes in its analysis family structure (e.g., married couples, single-mother families, single father families).

The purpose of this research is to investigate the direct effects to answer whether family structure contributes to delinquent acts. This study will expand the focus of the effect of living arrangement by examining its effect on not only substantiated delinquent acts overall but the type delinquent act (drug or person) by utilizing a series of logistic regression models to examine the relationship between family structure and juvenile delinquency.

It is recognized that "family forms have become increasingly diverse" (Schwartz, 2006, p. 1291) and shifts in American families over the past few decades have "considerably altered" living arrangements for children today (Demuth \& Brown, 2004, p. 58). In 2013, more than four in ten births were to unmarried women

*Address correspondence to this author at the York College of Pennsylvania, USA; E-mail: pverrecc@ycp.edu
(Child Trends, 2014). Research has demonstrated that children born to unmarried mothers are more likely to grow up in a single parent household, live in poverty, experience unstable living arrangements, and have socio-economic problems (Demo \& Cox, 2000; Haveman, Wolfe \& Pierce, 2001; McLanahan \& Sandefur, 1994; Thomas \& Sawhill, 2005). As these children reach adolescence they are more likely to have sex at a younger age, low educational achievement, and have birth outside of marriage (Aquillino, 1996; Carlson \& Corcoran, 2001; McLanahan \& Sandefur, 1994; Musick, 2002).

A majority of unmarried births occur in cohabiting parents (Kennedy \& Bumpass, 2008). In 2002, 20 percent of unmarried births were to cohabiting parents, but between 2006 and 2010 that number increased to 58\%. (Martinez, Daniels, \& Chandra, 2012). While these children are more likely to see their parents eventually marry than those born to non-cohabiting parents (Martinez, Daniels, \& Chandra, 2012), they are more likely to fare worse across a range of emotional and behavioral outcomes than those children born to married parents (Carlson, McLanahan \& England, 2004).

\section{LITERATURE REVIEW}

Vanassche, Sodermans, Metthijs and Swicegood studied the effect of family type on delinquency and alcohol use (2014). Using paper and pencil questionnaires with over 1,600 Flemish secondary school students, they found that children living in "nonintact families" were more likely to illegally drink alcohol, and that "high delinquent behavior" was more likely in boys from single parent families and girls in step families (Vanassche et al., 2014, p. 128). 
Studies have shown that strong connections between parents and children and high levels of parental involvement act as protective factors against risky behavior (see Boyer, 2006; Crouter \& Head, 2002). The Council of Economic Advisors (2000) found that children between the ages of 12 and 14 who ate dinner with a parent five or more days a week were less likely to smoke, have sex, and use alcohol and marijuana. Han, Miller and Waldfogel (2010) used the National Longitudinal Survey of Youth-Child Supplement to examine the effect of parental work schedules on adolescent behaviors and found that mothers who worked at night spent less time with their children and in turn these children were more likely to drink, smoke, and engage in delinquent behaviors.

Schroder, Osgood and Oghia (2010) explored the effect of family structure, family time and family attachment on juvenile delinquency. Where previous research has only examined family structure and juvenile delinquency, this one also looks at family time and attachment. Using the National Youth Survey, the researchers found that single parents in wave one of the survey that got married in wave three without having a good prior relationship with their children saw an increase in their child's juvenile delinquency. Children that continued to reside in two-parent homes committed the fewest number of delinquent acts and had the most interaction with their parents (Shroder et al., 2010).

Quensel, McArdle, Brinkley and Wiegersma (2002) examined the prevalence of delinquency related to family structures and peer associations. Over 3,000 juveniles $(n=3,386)$ were sampled from five U.S. cities. They were all attending school and had a mean age of 15. The researchers first looked at family structure and then peer association, then they compared the two to see which had a higher significance (Quensel et al., 2002). While they found that juveniles raised by single mothers had a higher risk for offending than those in nuclear families, peer associations also played a significant role in whether a juvenile was delinquent and one did not outweigh the other.

Shaw and Mckay evaluated the effect of broken homes in juvenile delinquency in 1932 and they argued that broken homes as a factor in juvenile delinquency was overstated. Their conclusions were due, in part, to their analysis of earlier work (see Burt, 1925; Slawson, 1926) that reported about twice the rate of broken homes for delinquent (institutionalized) youth as nondelinquent (noninstitutionalized) youth. Shaw and
McKay said that the previous analysis failed to control for other factors (age, nationality) that might be related to delinquency.

Nye (1958) examined the influence of family structure on delinquency and found that family structure did not exert a direct effect on delinquent behavior. Nye found an indirect effect through social controls provided by relationships within the family. He stated that children from single parent homes were more likely to be delinquent, which (he argued) came from a loss of direct parental controls and decreased attachments.

Research that has focused more on delinquent behavior (rather than problem behavior) consistently demonstrates that children from broken homes are more delinquent than children from intact families, but the effects of family structure are mediated, in a large part, by family process, such as supervision and closeness (Demuth \& Brown, 2004). Our understanding of the relationship between family structure and delinquency has been limited by defining family structure as broken or intact home and also by dichotomizing delinquent behavior (delinquent or not). Few scholars have examined the effect of the increasingly diverse living situations of American youth (Demuth \& Brown, 2004). This analysis, however, will expand the limited definition of family structure (broken vs. intact home) by considering delinquent youth residing with both birth parents, single mothers, single fathers, mother-stepfather families and fatherstepmother families, children living with relatives, and children living in foster families. Further, this study expands the dependent variable of delinquency to type of delinquency (holding delinquency constant-all of the youth in the sample have a substantiated delinquent act) by examining drug and person offenses.

\section{METHODS}

Since our dependent variable is being measured the interval/ratio level (number of delinquency dispositions) and is continuous this study will employ logistic regression for the analysis of the effect of family structure on type of delinquent behavior. To explore this, a quasi-experimental design is employed, with the type and number of delinquency disposition (person or drug) acting as the central dependent variable.

Data from the Pennsylvania Juvenile Court Judges' Commission's Disposition Report was utilized for this study. The JCJC annually publishes an overview of 
Table 1: Number of Alleged and Substantiated Charges for 2012

\begin{tabular}{|c|c|c|c|}
\hline Delinquent Act Type & Alleged & Substantiated & \% of Sample \\
\hline \hline Person Offense & 3,903 & 866 & 27.0 \\
\hline Drug Offense & 5,668 & 2,347 & 73.0 \\
\hline
\end{tabular}

juvenile court dispositions which summarizes juvenile court data compiled from Pennsylvania's 67 county juvenile probation departments. In 2012 there were 9,571 allegations of juveniles (ages 10-18) committing rape, robbery, aggravated assault, and drug related offenses (Pennsylvania Juvenile Court Judges' Commission, 2014). Of those 9,571 allegations, onethird $(n=3,213)$ were substantiated and those cases will be used for the basis of our analysis. Table 1 contains the number of alleged and substantiated delinquent acts for rape $(n=33)$, robbery $(n=448)$, aggravated assault ( $n=385)$ and drug offenses $(n=2,347)$ in Pennsylvania in 2012. Due to the unequal number of substantiated offenses, for our analysis we grouped all of the person offenses together $(n=866)$.

The Disposition Report is published at The Center for Juvenile Justice Training and Research (CJJT\&R). The Center was established by and is managed by the Juvenile Court Judges' Commission, a Commonwealth of Pennsylvania agency within the Governor's Office and its Office of General Counsel. In addition to providing a number of training and educational programs to juvenile justice professionals from across the Commonwealth of Pennsylvania, CJJT\&R also operates an Information and Technology Division that compiles data and publishes an annual report on the activities of all juvenile courts in Pennsylvania.

\section{Delinquency}

The measure of delinquency is substantiated delinquent act. Substantiations were chosen as the dependent variable in this study because a juvenile can be referred to the court and later have that referral revoked for a number of reasons (i.e. the juvenile did not commit the delinquent act). However, for a juvenile to go from referral to substantiation signifies that there is a guilty act so this represents a truer depiction of juvenile delinquency in Pennsylvania than utilizing referrals.

For this study a within-group analysis is being utilized therefore holding delinquent behavior constant. Prior research into the effects of child maltreatment (see Lemmon, 2006) on delinquency have utilized a within group analysis holding maltreatment constant because a between group (maltreated $v$. not maltreated) produced a false linear relationship (the maltreated youth had much higher rates of delinquency, while the not maltreated youth engaged in almost no delinquency). Previous within groups have been utilized in research with delinquents. Mosack, Gore-Felton, Chartier and McGarvey (2007) examined family structure variables with only incarcerated adolescents, but their research focused on sexual behavior and not delinquency.

\section{Family Structure}

Family structure was operationalized as a juvenile who committed a delinquent act who was living with both birth parents $(n=575)$, their birth mother only $(n=1,478)$, their birth father only $(n=270)$, a relative $(n=202)$, their birth father and stepmother $(n=45)$, their birth mother and stepfather $(n=183)$, or a foster family $(n=32)$. The 418 substantiated charges whose family structure information was either listed as other or not reported were excluded from the analysis. Table 2 contains the descriptive statistics for the independent variables.

Table 2: Descriptive Statistics for Family Structure

\begin{tabular}{|c|c|c|}
\hline Variable & N & $\%$ \\
\hline \hline Both Parents & 575 & 17.9 \\
\hline Birth Mother Only & 1,478 & 46.0 \\
\hline Birth Father Only & 270 & 8.4 \\
\hline Relative & 202 & 6.3 \\
\hline Birth Father and Step Mother & 45 & 1.4 \\
\hline Birth Mother and Step Father & 183 & 5.7 \\
\hline Foster Family & 32 & 1.0 \\
\hline Not Reported & 257 & 8.0 \\
\hline Other & 170 & 5.3 \\
\hline
\end{tabular}

\section{Analytic Plan}

The outcome of interest in this study is the substantiation rate for type of offense. To analyze the 
direct effects of each family structure variable on substantiated delinquent act regression analysis was employed. Two regression models were utilized to examine the effects of the family structure variables on drug or person offenses (the dependent variable) in the 67 counties in the Commonwealth of Pennsylvania.

This study will employ race (white and nonwhite ${ }^{1}$ ), gender, and age (10-15 and 16-18) as control variables. Research (Lieber \& Fox, 2005; O'Neill, 2004) shows that racial characteristics influence judicial outcomes. While some research (Dohrn, 2004; Verrecchia, 2009) has shown that females tend to get a harsher sentence than males in juvenile court, other researchers (Hawkins, Catalano, \& Miller, 1992; Hawkins, Catalano \& Brewer, 1995) have found being a female to be a protective factor when it comes to problem behavior. Finally, research has demonstrated that younger juveniles tend to be diverted from the system or handled informally than older juveniles (Mears, Cochran, Stults, Greenman, Bhati \& Greenwald, 2014). Table 3 contains the descriptive statistics for the control variables.

Table 3: Descriptive Statistics for Control Variables

\begin{tabular}{|c|c|c|}
\hline Variable & N & $\%$ \\
\hline \hline RACE & 1,481 & 46.1 \\
\hline White & 1,732 & 53.1 \\
\hline Non-White & 2,388 & 74.3 \\
\hline GENDER & 825 & 25.7 \\
\hline \multicolumn{3}{|c|}{ Male } \\
Female & 1481 & 46.1 \\
\hline AGE $\quad 1732$ & 53.9 \\
\hline $10-15$ & $16-18$ &
\end{tabular}

\section{RESULTS}

The first research question examined the effect of family structure on delinquency dispositions for drug offenses. The results of the regression analysis are presented in Table 4 . Of the seven family structure variables and three control variables, three had a significant effect on the number of substantiated drug offenses in Pennsylvania's counties. Two variables were related to family structure (living with both parents

\footnotetext{
${ }^{1}$ The nonwhite category was made up primarily of Blacks (69.6\%).
}

and living with birth father and stepmother) and the other was a control variable (age).

The second research question examined the effect of family structure on delinquency dispositions for person offenses. The results of the regression analysis are presented in Table $\mathbf{5}$. Of the seven family structure variables and three control variables two had a significant effect on the number of substantiated person offenses in Pennsylvania's counties; one family structure variable, living with mother and stepfather and one control variable, age.

\section{DISCUSSION}

The only predictor variable that had a significant relationship on both offense types id age, which is consistent with previous literature. Older juveniles (1618 ) in the sample were more likely to commit both drug and person offenses than younger (10-15) juveniles. Living with a father and stepfather seemed to increase the likelihood of committing a drug offense, which is fairly consistent with the literature. In terms of delinquent behavior, Halpern-Meekin and Tach (2008) found that "children in blended families have worse outcomes than children in simple two parent families" (p. 435). Children raised in stepfamilies have an increased chance of delinquent behavior compared to children raised by both biological parents (Amato, 2005; Case, Lin \& McLanhan, 1999; McLanhan \& Sandefur, 1994).

It has been argued (Cherlin, 1978) that remarriages are more likely to develop stressful family dynamics than first marriages. Perhaps the stress of a new living situation led some children to turn to drugs as a coping mechanism. This effect of remarriage seems to be borne out in the second model, where living with a mother and stepfather was the only significant family structure variable that was associated with committing a person offense. Living with both biological parents seemed to be a protective factor for committing a drug offense, since the significant relationship was negative $(\mathrm{t}=-2.511)$. However, there was no relationship between living with both parents and committing a person offense.

\section{LIMITATIONS}

"There is some controversy over the best approach to measuring delinquency" (Coughlin \& Vuchinich, 1996, p. 493), and using official measures of crime is viewed by some with skepticism due to the controversy 
Table 4: Standardized Regression Coefficients Representing Effects of Family Structure on Substantiated Drug Offenses

\begin{tabular}{|c|c|c|c|c|c|c|}
\hline & & b & S.E. & Wald & $\mathbf{t}$ & Sig. \\
\hline Both Parents & & $-.124^{* *}$ & .181 & 7.759 & -2.511 & .005 \\
\hline Birth Mother & & -.285 & .109 & 1.340 & -.478 & .139 \\
\hline Birth Father & & $.757^{A}$ & .574 & 3.244 & 1.983 & .078 \\
\hline Relative & & -.033 & .301 & 2.983 & -.094 & .254 \\
\hline Father and Stepmother & & $.330^{*}$ & 1.476 & 3.913 & 2.357 & .043 \\
\hline Mother and Stepfather & & .014 & .346 & 1.022 & .124 & .376 \\
\hline Foster Parents & & .008 & .825 & .987 & .096 & .598 \\
\hline Gender & & -1.018 & .096 & 4.102 & -1.377 & .431 \\
\hline Race & & .894 & .115 & 3.878 & .966 & .318 \\
\hline Age & & $.321^{* *}$ & .056 & 2.401 & 2.722 & .001 \\
\hline Constant & & & & $-2.850^{*}$ & 21.287 & \\
\hline $\mathrm{R}^{2}$ & .908 & & & & & \\
\hline Adjusted $^{2}$ & .888 & & & & & \\
\hline
\end{tabular}

${ }^{A} p<.10,{ }^{*} p<.05,{ }^{* *} p<.01$.

Table 5: Standardized Regression Coefficients Representing Effects of Family Structure on Substantiated Person Offenses

\begin{tabular}{|c|c|c|c|c|c|c|}
\hline & & b & S.E. & Wald & $t$ & Sig. \\
\hline Both Parents & & -.143 & .370 & 3.987 & -.506 & .398 \\
\hline Birth Mother & & .215 & .222 & 4.511 & .312 & .509 \\
\hline Birth Father & & .066 & 1.170 & 1.782 & .149 & .441 \\
\hline Relative & & .010 & .613 & 1.001 & .024 & .376 \\
\hline Father and Stepmother & & -.125 & 3.006 & 2.761 & -.773 & .209 \\
\hline Mother and Stepfather & & $.367^{* *}$ & .705 & 2.998 & 2.793 & .002 \\
\hline Foster Parents & & .016 & 1.680 & 1.222 & .174 & .291 \\
\hline Gender & & -1.000 & .195 & 3.214 & -1.167 & .311 \\
\hline Race & & 1.448 & .234 & 3.852 & 1.351 & .419 \\
\hline Age & & $.088^{* *}$ & .026 & 2.427 & 3.58 & .001 \\
\hline Constant & & & $-3.539^{\star *}$ & 43.350 & & \\
\hline $\mathrm{R}^{2}$ & .876 & & & & & \\
\hline Adjusted $^{2}$ & .849 & & & & & \\
\hline
\end{tabular}

${ }^{A} \mathrm{p}<.10,{ }^{*} \mathrm{p}<.05,{ }^{* \star} \mathrm{p}<.01$.

in the 1960s and 1970s over what official measures of crime actually measure-crime or crime control (Warner \& Pierce, 1993). For instance, studies have found that the size of the police force and expenditures for policing vary with the percentage of nonwhites in an area (Jackson \& Carroll, 1981; Liska \& Chamlin, 1984), which increases the potential of making an arrest. In addition, there are certain validity issues inherent in official measures of crime and delinquency (see Maxfield \& Babbie, 2014).
Bursik (1988) reviewed a variety of shortcomings of official arrest data. However, the current study utilizes substantiated offense as its dependent variable, not arrest. If there was any bias made in the arrest it can be assumed (or hoped) that this was discovered and dealt with before the case made its way to trial. For example, arrest practices in rural jurisdictions may be more informal than in urban/suburban jurisdictions. To control for potential bias of arrest statistics, researchers have examined other measures than arrest data, such 
as citizen complaint reports of crime to police (Warner \& Pierce, 1993), self-report of victims (Sampson \& Groves, 1989), and self-reports of offenders (Elliot, Huizinga, Sampson, Elliott \& Rankin, 1996). Osgood and Chambers (2000) point out that a "potential difficulty" in using arrest data is that people arrested in a given county may not live in that county (p. 92).

There is no doubt that counties encompass distinct communities that differ in levels of delinquency and that communities may differ from the average in terms of both the dependent (types of delinquency) and the independent (family structure) variables employed in this study. A possible drawback is that counties "do not best capture the neighborhood level processes...explaining family effects on community violence levels" (Schwartz, 2006, p. 1,296). However, Land, McCall and Cohen (1990) showed that structural correlates of crime are robust across levels of aggregation (city, county and state levels). In addition, Wilkinson (1984) believes that county data have "decided advantages" because they are the most complete. Schwartz (2006) used counties as the unit of analysis in her study because while "no single aggregate unit of analysis is entirely appropriate for the comparative analysis of the effects... of multiple forms of family structure" the "choice of counties...is more pragmatic than ideal" (p. 1,296). Therefore, as Osgood and Chambers (2000) noted, "County level analysis should provide a reasonable approximation to the relationships that would be found with more precisely defined communities" (p. 90-91). A further limitation is the use of data from one state, which limits generalizability.

\section{CONCLUSION}

One possible reason for the lack of significance in the models between family structure and delinquency type is that combining "diverse areas into one ecological unit may attenuate the strength of results and decrease the likelihood of identifying statistically significant relationships" (Schwartz, 2006, p. 1,296). While significance was found between living with a birth mother and stepfather with one of the dependent variables and living with a father and stepmother was significant on another, the limitations of this study make conjecture not only impossible but also unwise especially in light of the fact that results were not consistent across offense type. Noting that a relationship exists could spurn future research into child attachment (Gottfredson \& Hirshci, 1990), parenting practices (Simons, Wu, Conger \& Lorenz,
1994), peer relations (Coughlin \& Vuchinich, 1996), and perceived family support and "the importance of relationship quality (rather than just relationship type)" (Mosack, et al., 2007, p. 127). In pursuing this line of inquiry further it would be beneficial to consider how socio-economic factors might be examined in relation to family structure and delinquency.

\section{REFERENCES}

Amato, P. (2005). The impact of family formation change on the cognitive, social and emotional well-being in the next generation. The Future of Children (15), pp. 75-96. http://dx.doi.org/10.1353/foc.2005.0012

Aquilino, W.S. (1996). The life course of children born to unmarried mothers: Childhood living arrangements and young adult outcomes. Journal of Marriage and The Family, 58(2), 293310.

http://dx.doi.org/10.2307/353496

Boyer, T.W. (2006). The development of risk-taking: A multiperspective review. Developmental Review, 26, 291-345. http://dx.doi.org/10.1016/j.dr.2006.05.002

Burt, C. (1925). The Young Delinquents. London: University of London Press.

Carlson, M. \& Corcoran, M. (2001). Family structure and children's behavioral and cognitive outcomes. Journal of Marriage and the Family, 63(3), 779-792. http://dx.doi.org/10.1111/j.1741-3737.2001.00779.x

Carlson, M., McLanahan, S. \& England, PO. (2004). Union formation in fragile families. Demography, 412(2), 237-261. http://dx.doi.org/10.1353/dem.2004.0012

Case, A.; Lin, I.F. \& McLanahan, S. (1999). Household resource allocation in stepfamilies: Darwin reflects on the plight of Cinderella. American Economic Review (89), pp. 234-238. http://dx.doi.org/10.1257/aer.89.2.234

Cherlin, A. (1978). Remarriage as an incomplete institution. American Journal of Sociology (84), pp. 634-650. http://dx.doi.org/10.1086/226830

Child Trends (2014). Births to unmarried women. Indicators on Children and Youth. Retrieved from http://www.childtrends. org/?indicators=births-to-unmarriedwomen on September 19, 2014.

Coughlin, C. \& Vuchinich, S. (1996). Family experience in preadolescence and the development of male delinquency. Journal of Marriage and the Family (58), pp. 491-501. http://dx.doi.org/10.2307/353512

Crouter, A.C. \& Head, M.R. (2002). Parental monitoring and knowledge of children. In M.H. Bornstein (Ed.), Handbook of Parenting ( $2^{\text {nd }}$ ed.), pp. 461-482. Mahwah, NJ: Erlbaum.

Demo, D. \& Cox, M. (2000). Families with young children: A review of research in the 1990s. Journal of Marriage and the Family, 62(4), 876-895. http://dx.doi.org/10.1111/j.1741-3737.2000.00876.x

Demuth, S. \& Brown, S. L. (2004). Family structure processes, and adolescent delinquency: The significance of parental absence versus parental gender. Journal of Research in Crime and Delinquency (41), 1, 58-81. http://dx.doi.org/10.1177/0022427803256236

Dohrn, B. (2004). All Ellas: Girls locked up. Feminist Studies (30), pp. 302-324. http://dx.doi.org/10.2307/20458965

Halpern-Meekin, S. \& Tach, L. (2008). Heterogeneity in two-parent families and adolescent well being. Journal of Marriage and Family (70), pp. 435-451. http://dx.doi.org/10.1111/j.1741-3737.2008.00492.x 
Han, W., Miller, D.P. \& Waldfogel, J. (2010). Parental work schedule and adolescent risky behaviors. Developmental Psychology (46), 5, 1245-1267. http://dx.doi.org/10.1037/a0020178

Haveman, R., Wolfe, B. \& Pierce, K. (2001). Intergenerational effects of nonmarital and early childbearing. In L.L. Wu \& B. Wolfe (Eds.), Out of wedlock: Causes and consequences of nonmarital fertility. New York: Russell Sage Foundation.

Hawkins, J.D., Catalano, R.P. \& Miller, J.Y. (1992). Risk and protective factors for alcohol and other drug problems in adolescence and early adulthood: Implications for substance abuse prevention. Psychological Bulletin 112, 64-105. http://dx.doi.org/10.1037/0033-2909.112.1.64

Hawkins, J.D., R.F. Catalano \& D.D. Brewer (1995). Preventing serious, violent, and chronic juvenile offending: Effective strategies from conception to age 6. In J.C. Howell, B. Krisberg, J.D. Hawkins \& J.J. Wilson (Eds.) A sourcebook: Serious, violent, and chronic juvenile offenders (pp.47-60). Thousand Oaks CA: Sage.

Jackson, P.I., \& Carroll, L. (1981). Race and the war on crime: The sociopolitical determinants of municipal police expenditures in 90 non-Southern cities. American Sociological Review, 46, 290-305.

http://dx.doi.org/10.2307/2095061

Kennedy, S. \& Bumpass, L. (2008). Cohabitation and children's living arrangements: New estimations from the United States. Demographic Research, 19(47), 1663-1692. http://dx.doi.org/10.4054/DemRes.2008.19.47

Lemmon, J.H. (2006). The effects of maltreatment recurrence and child welfare services on dimensions of delinquency. Criminal Justice Review 31, 5-33. http://dx.doi.org/10.1177/0734016806287945

Lieber, M.J. \& Fox, K.C. (2005). Race and the impact of detention on juvenile Jjustice decision making. Crime and Delinquency (51), 4, pp. 470-497. http://dx.doi.org/10.1177/0011128705275976

Liska, Allen E., \& Chamlin, Mitchell B. (1984). Social structure and crime control among macrosocial units. American Journal of Sociology, 98, 383-395. http://dx.doi.org/10.1086/228084

Martinez, G.M., Daniels, K. \& Chandra, A. (2012). Fertility of men and women aged 15-44 years in the United States: National survey of family growth, 2006-2010. National Health Statistics Reports, 51. Hyattsville, MD: National Center for Health Statistics. Table 12.

Maxfield, M.G. \& Babbie, E. (2014). Research Methods for Criminal Justice and Criminology ( $7^{\text {th }}$ Edition). Independence, KY: Cengage Learning

Mears, D.P., Cochran, J.C., Stults, B.J., Greenman, S.J., Bhati, A.S. \& Greenwald, M.A. (2014). The "true" juvenile offender: Age effects and juvenile court sanctioning. Criminology, 52(2), 169-194.

http://dx.doi.org/10.1111/1745-9125.12034

McLanahan, S. \& Sandefur, G. (1994). Growing up With a Single Parent: What Hurts, What Helps? Cambridge, MA: Harvard University Press.

Mosack, K.E., Gore-Felton, C., Chartier, M., \& McGarvey, E. (2007). Individual, peer, and family variables associated with risky sexual behavior among male and female incarcerated adolescents. Journal of HIV/AIDS Prevention in Children \&b Youth (8), 1, pp. 115-133.

http://dx.doi.org/10.1300/J499v08n01 07

Musick, K. (2002). Planned and unplanned childbearing among unmarried women. Journal of Marriage and the Family, 64(4), 915-929.

http://dx.doi.org/10.1111/j.1741-3737.2002.00915.x

Nye, F. I. (1958). Family Relationships and Delinquent Behavior. New York: John Wiley and Sons.

O'Neill, B.F. (2004). Influences on dispositions decisions in the juvenile justice system. Journal of Juvenile Justice Services (19), $1 / 2$, pp. 29-46.

Osgood, D.W. \& Chambers, J.F. (2000). Social disorganization outside the metropolis: An analysis of rural youth violence. Criminology, 38(1), 81-115. http://dx.doi.org/10.1111/j.1745-9125.2000.tb00884.x

Pennsylvania Juvenile Court Judges' Commission. (2014). Pennsylvania Juvenile Court Dispositions, 2012. Harrisburg, PA: Pennsylvania Juvenile Curt Judges' Commission.

Quensel, S., McArdle, P., Brinkley, A., \& Wiegersma, A. (2002). Broken home or drug using peers: "Significant relations"? The Journal of Drug Issues, 32(2), 467-489. http://dx.doi.org/10.1177/002204260203200209

Rankin, J. H. \& Kern, R. (1994). Parental attachments and delinquency. Criminology, 32, 495-515. http://dx.doi.org/10.1111/j.1745-9125.1994.tb01163.x

Sampson, R. \& Groves, W. B. (1989). Community structure and crime: Testing social-disorganization theory. American Journal of Sociology, 94, 774-802. http://dx.doi.org/10.1086/229068

Schroeder, R., Osgood, A., \& Oghia, M. (2010). Family transitions and juvenile delinquency. Sociological Inquiry, 80(4), 579604.

http://dx.doi.org/10.1111/j.1475-682X.2010.00351.x

Schwartz, J. (2006). Effects of diverse forms of family structure on female and male homicide. Journal of Marriage and Family (68), pp. 1291-1312. http://dx.doi.org/10.1111/j.1741-3737.2006.00329.x

Shaw, C. R. \& McKay, H. D. (1932). Are broken homes a causative factor in juvenile delinquency? Social Forces, 10, 514-524. http://dx.doi.org/10.2307/2569899

Thomas \& Sawhill (2005). For love and money? The impact of family structure on family income. The Future of Children, 15(2), 5774 http://dx.doi.org/10.1353/foc.2005.0020

Vanassche, S., Sodermans, A.K., Matthijs, K. \& Swicegood, G. (2014). The effects of family type, family relationships and parental role models on delinquency and alcohol use among Flemish adolescents.

Verrecchia, P.J. (2009). Female delinquents and restorative justice. Women and Criminal Justice (19), 1, pp. 80-93. http://dx.doi.org/10.1080/08974450802586992

Warner, B.D., \& Pierce, G.L. (1993). Reexamining socia disorganization theory using calls to the police as a measure of crime. Criminology, 31(4), 493-517. http://dx.doi.org/10.1111/j.1745-9125.1993.tb01139.x

Received on 12-01-2015

Accepted on 23-02-2015

Published on 13-03-2015

\section{DOI: http://dx.doi.org/10.6000/1929-4409.2015.04.06}

(c) 2015 Verrecchia and Arp; Licensee Lifescience Global.

This is an open access article licensed under the terms of the Creative Commons Attribution Non-Commercial License (http://creativecommons.org/licenses/by-nc/3.0/) which permits unrestricted, non-commercial use, distribution and reproduction in any medium, provided the work is properly cited. 